\title{
Apoptotic mechanism activated by blue light and cisplatinum in cutaneous squamous cell carcinoma cells
}

\author{
MARIA FIORELLA TARTAGLIONE ${ }^{1 *}$, MARÍA ELÉXPURU ZABALETA ${ }^{1 *}$, RAFFAELLA LAZZARINI ${ }^{1}$, \\ FRANCESCO PIVA $^{2}$, ELENA MARINELLI BUSILACCHI ${ }^{3}$, ANTONELLA POLONI $^{3}$, CATERINA LEDDA $^{4}$, \\ VENERANDO RAPISARDA ${ }^{4}$, LORY SANTARELLI $^{1}$ and MASSIMO BRACCI ${ }^{1}$
}

\begin{abstract}
${ }^{1}$ Section of Occupational Medicine, Department of Clinical and Molecular Sciences, Polytechnic University of Marche, I-60126 Ancona; ${ }^{2}$ Department of Specialistic Clinical and Odontostomatological Sciences, Polytechnic University of Marche, I-60131 Ancona; ${ }^{3}$ Section of Hematology, Department of Clinical and Molecular Science, Polytechnic University of Marche, I-60126 Ancona; ${ }^{4}$ Section of Occupational Medicine, Department of Clinical and Experimental Medicine,
\end{abstract} University of Catania, I-95124 Catania, Italy

Received May 18, 2020; Accepted January 18, 2021

DOI: $10.3892 / \mathrm{ijmm} .2021 .4881$

\begin{abstract}
New approaches are being studied for the treatment of skin cancer. It has been reported that light combined with cisplatinum may be effective against skin cancer. In the present study, the effects of specific light radiations and cisplatinum on A431 cutaneous squamous cell carcinoma (cSCC) and HaCaT non-tumorigenic cell lines were investigated. Both cell lines were exposed to blue and red light sources for 3 days prior to cisplatinum treatment. Viability, apoptosis, cell cycle progression and apoptotic-related protein expression levels were investigated. The present results highlighted that combined treatment with blue light and cisplatinum was more effective in reducing cell viability compared with single treatments. Specifically, an increase in the apoptotic rate was observed when the cells were treated with blue light and cisplatinum, as compared to treatment with blue light or cisplatinum alone. Combined treatment with blue light and cisplatinum also caused cell cycle arrest at the $\mathrm{S}$ phase. Treatment with cisplatinum following light exposure induced the expression of apoptotic proteins in the A431 and HaCaT cell lines, which tended to follow different apoptotic mechanisms. On the whole, these data indicate that blue light combined with cisplatinum may be a promising treatment for $\mathrm{cSCC}$.
\end{abstract}

Correspondence to: Professor Lory Santarelli or Professor Massimo Bracci, Section of Occupational Medicine, Department of Clinical and Molecular Sciences, Polytechnic University of Marche, Via Tronto 10/A, I-60126 Ancona, Italy

E-mail: 1.santarelli@univpm.it

E-mail: m.bracci@univpm.it

*Contributed equally

Key words: skin cancer, blue light, cisplatinum, A431 cells, HaCaT cells, LED light, light therapy, cSCC, apoptosis, cytotoxicity

\section{Introduction}

The skin is a complex tissue composed of two different compartments: The epidermis, comprised mostly of keratinocytes, and the underlying dermal matrix, with fibroblasts as its major cellular component (1). Cutaneous squamous cell carcinoma (cSCC) is characterized by the abnormal proliferation of keratinocytes, which leads to the development of tumors, principally of the scalp, face and the back of the hand (2). It is the most widespread type of skin cancer and is followed by basal cell carcinoma (3). Over the last decades, the incidence of cSCC has increased by $10 \%$ per year (4), mostly among the young population (5). Although this type of skin cancer is characterized by an intricate etiology, which often leads to misdiagnosis, exposure to ultraviolet (UV) radiation may be the primary cause of cSCC, resulting in DNA damage (6). cSCC is associated with a high degree of malignancy and an elevated level of invasion (7). Indeed, recurrent cSCC is associated with a higher risk of aesthetic co-morbidity, the development of distant metastasis and mortality (8).

Radiation therapy, chemotherapy, biological therapies and surgery are conventional treatments for $\operatorname{cSCC}(9,10)$. The primary treatment regimen selected by oncologists is early surgical intervention. However, the invasiveness of the procedure causes marked esthetical changes that often cause high psychological distress to the patients (11). In addition, several side-effects of long-term chemotherapy have been reported, including chemoresistance, fibrosis, necrosis and secondary tumor development (12). On the other hand, the radiotherapy regimen can cause skin complications, such as exudation, dermatitis, peeling and ulcers resulting from the inflammation caused by this type of treatment (13). Therefore, the development of potential alternative therapies is necessary for $\mathrm{cSCC}$.

Cisplatinum [cis-diammine-dichloroplatinum (II)] is a potent chemotherapeutic agent widely used in the treatment of skin cancer (14-16), among a wide variety of tumor types, including testicular $(17,18)$, ovarian $(19,20)$, cervical $(21-24)$, head and neck $(25-27)$ and lung $(28,29)$ cancer. It has been 
observed that cisplatinum induces DNA damage and blocks cell cycle progression at the specific $\mathrm{G}_{2} / \mathrm{M}$ checkpoint (30), leading to the induction of apoptosis of proliferating cells (31). However, it has a relatively high cytotoxic activity and, consequently, its application must be limited to the prevention of side-effects, such as ototoxicity and neurotoxicity (32), which are considered dose-limiting effects (33). Clinicians have therefore developed a strategy with which to restrict the cytotoxicity of cisplatinum, which includes its combination with non-platinum-based drugs, such as topoisomerase inhibitors, antimetabolites and taxanes $(34,35)$. However, numerous pre-clinical and clinical studies conducted on these combined therapies have yielded contradictory results, which seemed to depend on the treatment regimen and tumor cell features $(12,34,35)$.

The primary beneficial effects of light-emitting diode (LED) application on human health were found by the National Aeronautics and Space Administration, with the development of LEDs that produce a narrow spectrum of light in a non-coherent manner, delivering the appropriate and required wavelength and intensity (36). Over the past 15 years, LED technology has continuously improved $(36,37)$. Current LED therapy has the great advantage of high flexibility and adaptability that allows for the treatment of a wide variety of skin conditions exhibiting different biological effects. Its mechanism of action, namely photo-biomodulation, consists of the collective effects of 3 elements (a photosensitizing agent, a light source and oxygen) interacting contemporaneously (38). The source emits a light whose energy and wavelength emission activate the photosensitizer (38). In addition to the amount of energy, photo-biomodulation also depends on the irradiation time (36). LED therapy has been approved by the US Food and Drug Administration for its use by aestheticians, due to its capacity to increase ATP and transcription factor production, regulate oxidative stress and modulate collagen synthesis (37).

Therapeutic LED application has been improved and its use has increased in the treatment of several clinical conditions, such as lung-related diseases $(39,40)$, age-associated macula deterioration (41) and different types of solid tumors $(37,42)$. LEDs can generate different wavelengths, which lead to different biological activities. However, the effects induced by the blue light are not yet fully understood. It has been observed that, in the skin and retina, blue light induces suspected mediators of skin aging and age-related macular degeneration (36). The disruption of key cellular processes, such as mitosis and mitochondrial activity as a consequence of blue-light application (43) and the maintenance of DNA integrity (44) have been widely reported. The latest analyses focused on the modulation of cell signaling pathways by light energy $(45,46)$, which includes UV wavelengths or energies belonging to the visible light range $(37,47,48)$. Numerous studies have suggested that UVA light (320-400 nm) may stimulate anti-inflammatory and antioxidative cytoprotective pathways $(49,50)$, playing a key anti-tumorigenic role (51). Previous in vitro and in vivo investigations on skin cancer have revealed that blue LED induces the apoptosis of cancer cells (52) and a reduction of tumor growth in mice (51). In addition, it has been demonstrated that blue LED irradiation triggers apoptotic cell death through the mitochondria-mediated intrinsic pathway and shortens the early stage of tumor growth in melanoma cells (36).
Accordingly, the expression of numerous genes associated with tumorigenesis and cell metastasis is inhibited following exposure to blue LED (36).

The combination of standard therapeutic approaches has been recently attracting the attention of researchers and physicians for cancer treatment (53). On the other hand, light therapy and its combination with chemical drugs have also been shown to have a high therapeutic efficacy $(12,54)$. This is an important advantage, since the dose of single drugs can be reduced, leading to a reduction in adverse side-effects, while also maintaining treatment efficacy (55).

In the present study, the photobiological effects of blue and red light associated with the cisplatinum treatment of A431 and $\mathrm{HaCaT}$ skin cell lines were investigated to determine whether a combined treatment can increase the apoptotic rate, as compared with single cisplatinum or light treatment. If that is found to be the case, combination treatment could be proven to be a promising treatment for skin cancer.

\section{Materials and methods}

Cells lines and culture conditions. The A431 epidermoid carcinoma cell line (ECACC 85090402) was purchased from Merck Life Sciences (Merck Life Science). The HaCaT non-tumorigenic keratinocyte cell line was used as a control and was acquired from the Experimental Zooprophylactic Institute of Lombardia and Emilia Romagna (Brescia, Italy). The HaCaT cell line can be used as non-tumor control of the A431 cells (56-60) and it is considered a reliable model for skin diseases and for in vitro carcinogenesis of human skin keratinocytes $(61,62)$. The HaCaT and A431 cell lines were cultured under the same culture conditions to prevent differences in phototoxicity related to different growth mediums. The cell lines were cultured in high-glucose DMEM (Euroclone S.p.A.) supplemented with $10 \%$ fetal bovine serum (FBS; Euroclone S.p.A.) and $1 \%$ penicillin/streptomycin antibiotics (Euroclone S.p.A.) at $37^{\circ} \mathrm{C}$ in an atmosphere containing $5 \% \mathrm{CO}_{2}$. Both cell lines were sub-cultured every 3-4 days. Both cell lines were mycoplasma-free.

Light exposure. Prior to light exposure, the cells were gradually starved to synchronize the cell cycle. Both cell lines were first cultured with low-glucose DMEM (Euroclone S.p.A.) supplemented with $0.1 \% \mathrm{FBS}$ and $1 \%$ penicillin/streptomycin for $24 \mathrm{~h}$ and then DMEM without phenol red (Lonza Group, Ltd.), also complemented with $0.1 \%$ FBS and $1 \%$ penicillin/streptomycin for a further $24 \mathrm{~h}$.

Samples were exposed to sham, blue, or red single-color LEDs in a specific incubator at $37^{\circ} \mathrm{C}$ and $5 \% \mathrm{CO}_{2}$ for 3 days. Constant darkness was considered the sham light source, while light exposures were performed in a 12-h light/dark cycle (12L:12D). High-power blue and red LEDs (LD W5AM and LH W5AM Golden DRAGON ${ }^{\circledR}$ Plus, respectively; Osram) were used as the light sources. The LED viewing angle was $170^{\circ}$ and the cells were placed at $14 \mathrm{~cm}$ above the light sources. The homogenous distribution of light and the spectrum of emission of each monochromatic LED were previously verified using an illuminance meter (CL-70; Konica Minolta Sensing, Inc.). The dominant wavelength was $465 \mathrm{~nm}$ for blue and $658 \mathrm{~nm}$ for red LEDs. Irradiance at peak wavelength at the cell surface 
was $0.84 \mathrm{~W} / \mathrm{m}^{2}$ for blue and $1.10 \mathrm{~W} / \mathrm{m}^{2}$ for red LEDs, corresponding to the same total spectrum irradiance of $28.50 \mathrm{~W} / \mathrm{m}^{2}$ for both light sources. The light energy transferred each day to cells was $1.23 \mathrm{~J} / \mathrm{mm}^{2}$. The light exposure was set to reproduce the solar radiation as precisely as possible (63). Blue and red lights were specifically selected to test the opposite sides of the spectrum of visible light. Interference between light sources was prevented by using black curtains; sham exposure was additionally ensured by wrapping the plate with aluminum foil. LEDs in the incubator were fixed on an aluminum tank by thermal conductive paste, and the water circulation inside the tank (Amersham Multitemp III; GE Healthcare) extracted the heat generated by the LEDs, so they could work at a constant temperature. These conditions assured a constant electric current and therefore a constant emitted energy. Air circulation inside the incubator was ensured using a fan. To exclude any thermal effects, the temperature at the cell level was verified and constantly measured during experiments with Thermochron iButton DS1922L (Maxim Integrated). On the fourth day from the time of the start of sham or light exposure, the cells were transferred to the previous incubator and started the cisplatinum treatment.

Cisplatinum treatment. Cisplatinum (Merck KGaA) was dissolved in physiological solution at a final stock concentration of $3 \mathrm{mM}$ and stored at $-20^{\circ} \mathrm{C}$ until use. The appropriate concentration of cisplatinum in distilled water was assessed for each cell line through the estimation of the half-maximal inhibitory concentration $\left(\mathrm{IC}_{50}\right)$ resulting after $24 \mathrm{~h}$ in $18 \mu \mathrm{M}$ for $\mathrm{A} 431$ cells and $30 \mu \mathrm{M}$ for HaCaT cells (data not shown). Each group, following light exposure, was divided into 2 subgroups, treated or not treated with the half-maximal inhibitory concentration $\left(\mathrm{IC}_{50}\right)$ of cisplatinum for $24 \mathrm{~h}$ at $37^{\circ} \mathrm{C}$ and $5 \%$ of $\mathrm{CO}_{2}$, and were then analyzed. Images of the cells were acquired on an inverted microscope (Leitz Fluovert; Leica Microsystems, Inc.) equipped with a digital camera (Canon EOS M50; Canon, Inc.).

5-Fluorouracil (5-FU) treatment. 5-FU (Merck KGaA), which was used for the data shown in the supplementary figures, was dissolved in physiological solution at a final stock concentration of $3.84 \mathrm{mM}$. The appropriate concentration of 5-FU in distilled water was assessed for each cell line by estimating the $\mathrm{IC}_{50}$ after $72 \mathrm{~h}$ in $75 \mu \mathrm{M}$ for A431 cells and $100 \mu \mathrm{M}$ for HaCaT cells. Each group, following light exposure, was divided into 2 subgroups, treated or not treated with the $\mathrm{IC}_{50}$ of 5-FU for $72 \mathrm{~h}$ at $37^{\circ} \mathrm{C}$ and $5 \%$ of $\mathrm{CO}_{2}$; cell viability assay was then performed.

Cell viability assay. To assess the effects of cisplatinum and light on cell viability, an XTT assay was performed, following the manufacturer's instructions (Cell Proliferation Kit II XTT; Merck KGaA). Briefly, the A431 and HaCaT cells were seeded in 96-well plates (Corning Inc.) at a final concentration of $1.6 \times 10^{4}$ cells/well and exposed to a cycle of 12L:12D (blue or red light) for 3 days; constant darkness was used as control. Subsequently, the appropriate concentration of cisplatinum for each cell line was added. At 24 h, $50 \mu 1$ XTT (2,3-bis-(2-met hoxy-4-nitro-5-sulfophenyl)-2H-tetrazolium-5-carboxanilide) solution was added to each well, followed by incubation for $2 \mathrm{~h}$ at $37^{\circ} \mathrm{C}$ and $5 \% \mathrm{CO}_{2}$. Finally, the absorbance at $450 \mathrm{~nm}$ with $650 \mathrm{~nm}$ as the reference wavelength was measured using an absorbance microplate ELISA plate reader (Sunrise ${ }^{\mathrm{TM}}$ Absorbance Reader; Tecan Group Ltd.).

Apoptosis analysis. The apoptotic rate of both cell lines was evaluated using an Annexin V/Propidium Iodide (PI) apoptosis detection kit (eBioscience ${ }^{\mathrm{TM}}$ Annexin V-FITC Apoptosis Detection kit; Thermo Fisher Scientific, Inc.), according to the manufacturer's instructions. Cells were seeded in a 6-well plate (Corning Inc.) at a concentration of $2 \times 10^{5}$ cells $/ \mathrm{ml}$. Following treatment with light and cisplatinum, cells were harvested, centrifuged $\left(770 \times \mathrm{g}\right.$ for $5 \mathrm{~min}$ at $4^{\circ} \mathrm{C}$ ), and washed with phosphate-buffered saline (PBS; Euroclone). The cells were then resuspended in binding buffer plus Annexin $\mathrm{V}$ following 10 min of incubation at room temperature in the dark. Finally, cells were stained with PI and assessed using the FACSCalibur flow cytometer (BD Biosciences) equipped with Cell Quest software set on a logarithmic scale (BD Biosciences). A minimum of 20,000 cells was acquired for each sample. Data were analyzed using FlowJo ${ }^{\mathrm{TM}}$ Software (FlowJo ${ }^{\mathrm{TM}}$ Software for Windows version 7.6.1.; FlowJo LLC).

Cell cycle analysis. The A431 and HaCaT cells were seeded in a 6 -well plate (Corning Inc.) at a concentration of $2 \times 10^{5}$ cells $/ \mathrm{ml}$. Following treatments, the cells were harvested and centrifuged at $300 \mathrm{x} \mathrm{g}$ for $6 \mathrm{~min}$ at room temperature, fixed with $4.5 \mathrm{ml}$ cold ethanol solution (70\% in PBS) and kept in ice at $4{ }^{\circ} \mathrm{C}$ for at least $2 \mathrm{~h}$. The cells were then washed twice with PBS before being resuspended in PI staining solution with $0.1 \%$ Triton $\mathrm{X}-100$ (Santa Cruz Biotechnology, Inc.), RNAse $0.2 \mathrm{mg} / \mathrm{ml}$ (Merck $\mathrm{KGaA}$ ) and PI $2 \mathrm{mg} / \mathrm{ml}$ (Merck KGaA) and incubated at $37^{\circ} \mathrm{C}$ for $15 \mathrm{~min}$. Flow cytometric analysis was performed using a FACSCalibur $^{\mathrm{TM}}$ flow cytometer (BD Biosciences) equipped with CellQuest software set on a linear scale (BD Pharmingen). A minimum of 20,000 cells was acquired for each sample. Data were analyzed using FlowJo ${ }^{\mathrm{TM}}$ Software.

Western blot analysis. To analyze protein expression, western blot analysis was performed. Proteins were extracted with RIPA buffer (50 mM Tris-HCl pH 7.4, 1\% NP-40, 0.1\% SDS, $150 \mathrm{mM}$ $\mathrm{NaCl}$, and $2 \mathrm{mM}$ EDTA + protease inhibitors) as follows: Cells were lysed and maintained in ice for $30 \mathrm{~min}$, with vortexing every $10 \mathrm{~min}$. The cells were then centrifuged (Eppendorf ${ }^{\circledR}$ Microcentrifuge 5415; Merck KGaA) at 16,000 x g for $20 \mathrm{~min}$ at $4^{\circ} \mathrm{C}$. Supernatants were collected and protein concentrations were measured using a Bradford assay (Merck KGaA). Protein $(30 \mu \mathrm{g})$ was treated with LDS Sample Buffer (Thermo Fisher Scientific, Inc.) and a Sample Reducing Agent (Thermo Fisher Scientific, Inc.). The tubes were then boiled at $100^{\circ} \mathrm{C}$ for $5 \mathrm{~min}$. Finally, equal amounts of protein $(30 \mu \mathrm{g})$ were resolved on precast $4-12 \%$ sodium dodecyl sulfate-polyacrylamide gel electrophoresis (Bolt 4-12\% Bis-Tris Plus; Thermo Fisher Scientific, Inc.) in MES SDS running buffer (Thermo Fisher Scientific, Inc.) at $100 \mathrm{~V}$ and $35 \mathrm{~mA}$, before entering the gel, and at $165 \mathrm{~V}$ and $60 \mathrm{~mA}$ after entering the gel. A protein ladder (SeeBlue ${ }^{\mathrm{TM}}$ Plus2 Prestained Standard; Thermo Fisher Scientific, Inc.) was used as a reference for protein size. Following running, proteins were transferred to a nitrocellulose membrane (NC; Amersham ${ }^{\mathrm{TM}}$ Protran $^{\mathrm{TM}}$ Nitrocellulose Blotting Membrane; GE Healthcare) using a semi-dry method 
A

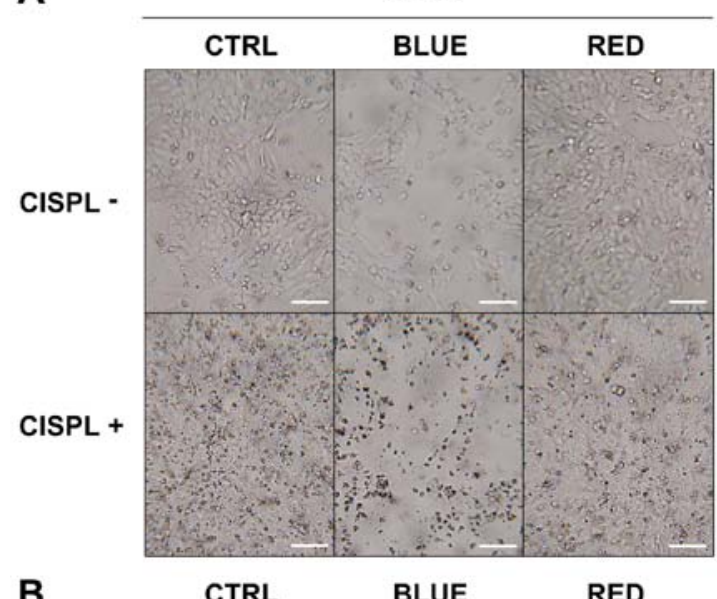

B

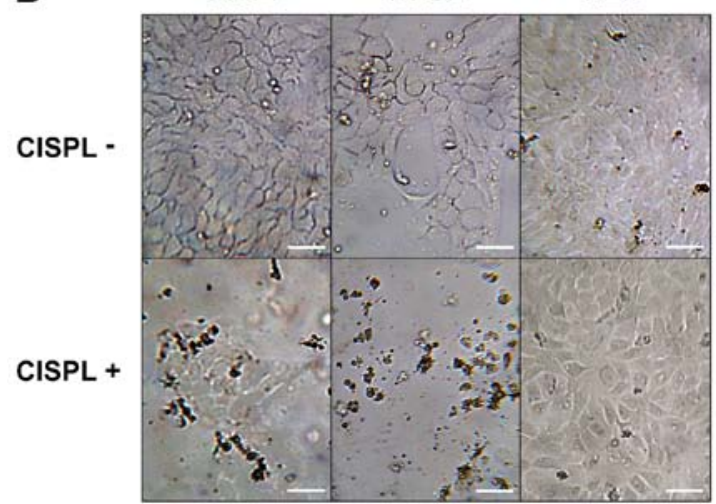

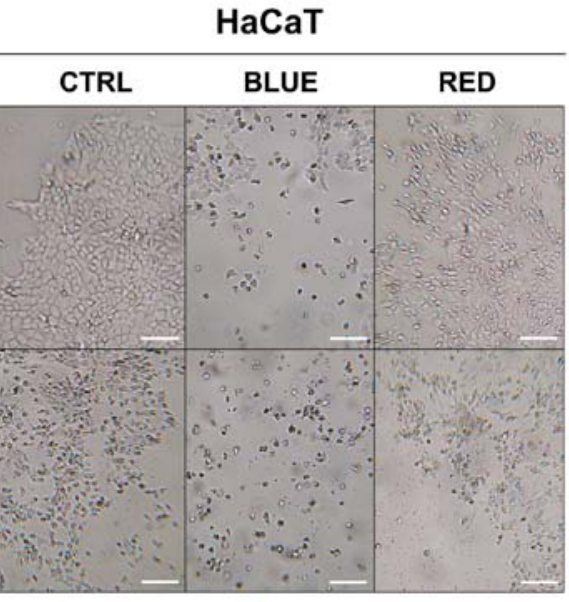

CTRL

BLUE

RED

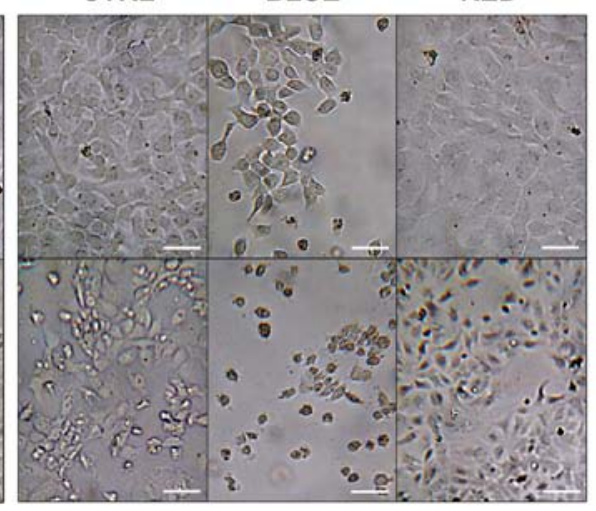

Figure 1. Morphology of A431 and HaCaT cells exposed to LED, cisplatinum, and LED and cisplatinum combined. Representative images captured at magnifications of (A) x100 and (B) x200 magnification in A431 and HaCaT cell lines. Scale bars, (A) $60 \mu \mathrm{m}$ and (B) $30 \mu \mathrm{m}$. LED, light-emitting diode.

in transfer buffer (Tris $25 \mathrm{mM}, 0.2 \mathrm{M}$ glycine, $20 \%$ methanol). The transfer was performed at $30 \mathrm{~V}$ and an amperage calculated based on the membrane's measurements ( $\mathrm{w} \times \mathrm{h} \times 0.8$ ). The protein transfer was verified by immersing the membrane in red Ponceau [Ponceau S solution for electrophoresis $(0.2 \%)$; SERVA Electrophoresis $\mathrm{GmbH}$ ] and then washed 3 times for 5 min with PBS-Tween-20 (PBST) 0.1\%. Subsequently, the membrane was blocked with 5\% milk-PBST (non-fat dried milk; Euroclone S.p.A.) for $1 \mathrm{~h}$ at room temperature and then incubated overnight at $4^{\circ} \mathrm{C}$ with pertinent primary antibodies: Rabbit polyclonal anti-human anti-Gapdh antibody (dilution, 1:1,000; cat. no. A300-639A-M; Bethyl Laboratories Inc.), rabbit polyclonal anti-human anti-caspase-9 (Casp-9; dilution, 1:1,000; cat. no. 9502; Cell Signaling Technology, Inc.), mouse monoclonal anti-human anti-caspase-8 (Casp-8; dilution, 1:1,000; cat. no. 9746; Cell Signaling Technology, Inc.), mouse monoclonal anti-human anti-caspase-3 (Casp-3; dilution, 1:500; cat. no. sc-7272; Santa Cruz Biotechnology, Inc.), rabbit polyclonal anti-human anti-BH3 interacting domain death agonist (Bid; dilution, 1:1,000; cat. no. 2002; Cell Signaling Technology, Inc.), rabbit polyclonal anti-human anti-Bcl-2-associated X protein (Bax; dilution, 1:1,000; cat. no. 2772; Cell Signaling Technology, Inc.), mouse monoclonal anti-human anti-cytochrome $c$ (Cyt $c$; dilution, 1:1,000; cat. no. sc-13156; Santa Cruz Biotechnology, Inc.), rabbit monoclonal anti-human anti-p53 (dilution, 1:1,000; cat. no. 2527; Cell Signaling Technology, Inc.) and rabbit polyclonal anti-human anti-apoptosis independent factor (Aif; dilution,
1:1,000; cat. no. 4642; Cell Signaling Technology, Inc.). The following day, the NC membrane was washed 3 times with PBST $0.1 \%$ and incubated with corresponding horseradish peroxidase (HRP)-conjugated secondary antibodies at room temperature for $3 \mathrm{~h}$ : Goat anti-rabbit $\operatorname{IgG}(\mathrm{H}+\mathrm{I})$ peroxidase/HRP-conjugated (dilution, 1:3,000; cat. no. E-AB-K1813; Elabscience Biotechnology, Inc.) or goat anti-mouse IgG $(\mathrm{H}+\mathrm{I})$ FITC conjugated (dilution, 1:10,000; cat. no. A90-116F; Bethyl Laboratories, Inc.). Finally, another 3 5-min washes with PBST were performed prior to membrane development. For signal chemiluminescent detection, the membrane was incubated for 2 min in the dark at room temperature with SuperSignal ${ }^{\mathrm{TM}}$ West Femto Maximum Sensitivity Substrate (Thermo Fisher Scientific, Inc.) and then developed in Alliance Mini (UVITEC Cambridge) equipped with NineAlliance Software (UVITEC Cambridge). Band quantification was carried out using the same software. Membrane stripping was performed prior to the addition of Gapdh where similar molecular weight proteins were previously assessed.

Statistical analysis. Experiments were conducted in triplicate, and the results were reported as the means \pm standard deviation (SD) from 3 independent experiments. Graphpad Prism software (version 7.00 for Windows; GraphPad Software, Inc.) was used for all statistical analysis. One-way ANOVA and Tukey's HSD post hoc test was used to evaluate statistical significance. $\mathrm{P}<0.05$ was considered to indicate a statistically significant difference. 


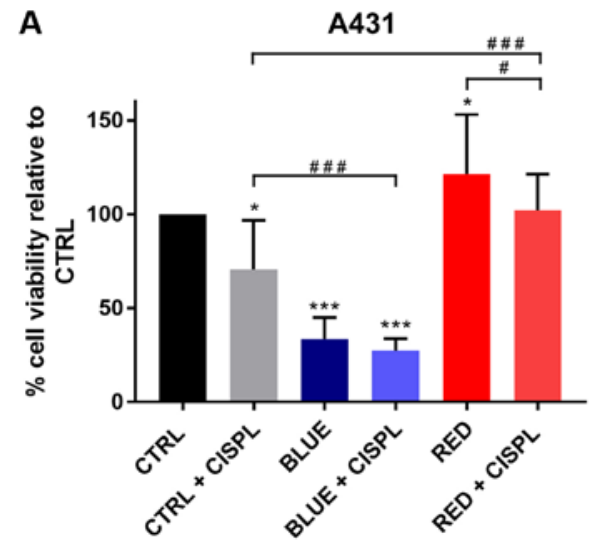

B

$\mathrm{HaCaT}$

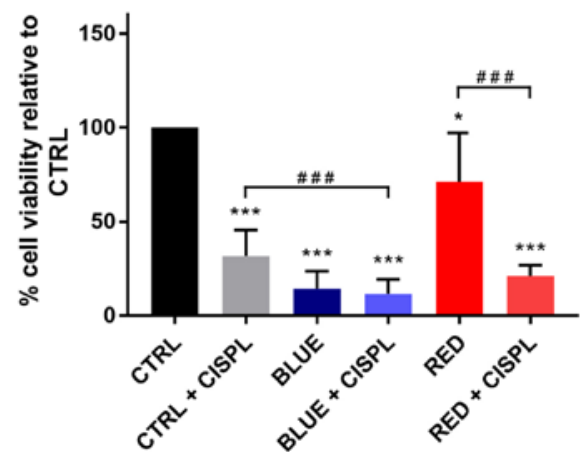

Figure 2. Analysis of cell viability in (A) A431 and (B) HaCaT cell lines exposed to LED, cisplatinum, and LED and cisplatinum combined. Columns represent mean values and bars represent $\pm \mathrm{SD}(\mathrm{n}=3) .{ }^{*} \mathrm{P}<0.05$ and ${ }^{* * *} \mathrm{P}<0.001$ vs. CTRL. ${ }^{*} \mathrm{P}<0.05$ and ${ }^{\# \# \#} \mathrm{P}<0.001$. LED, light-emitting diode; SD, standard deviation.
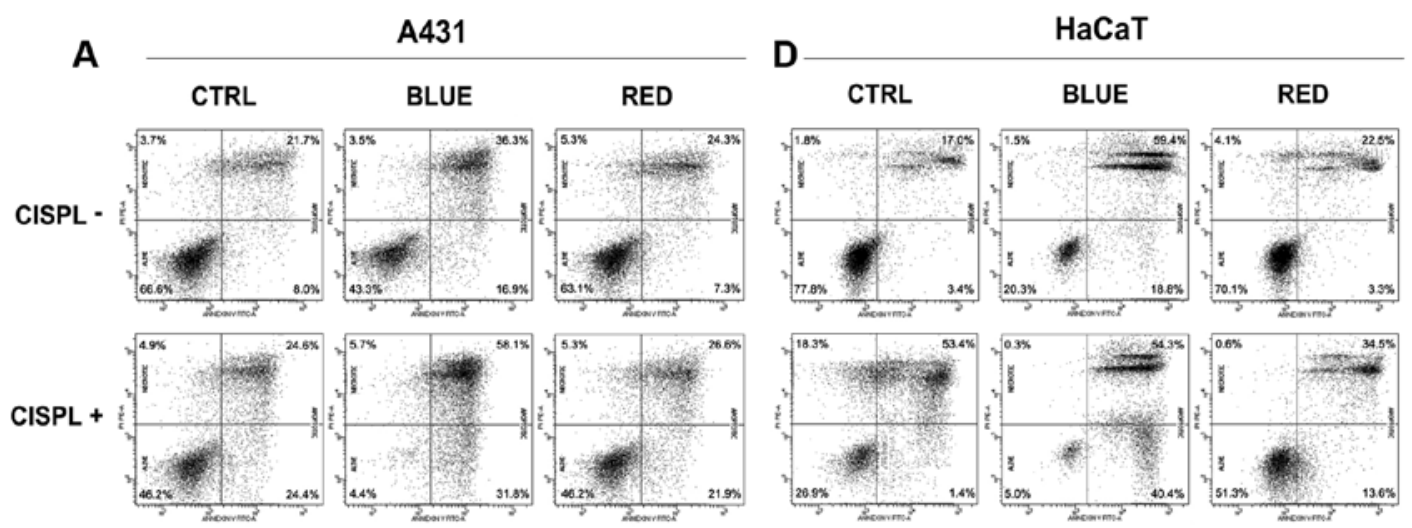

B

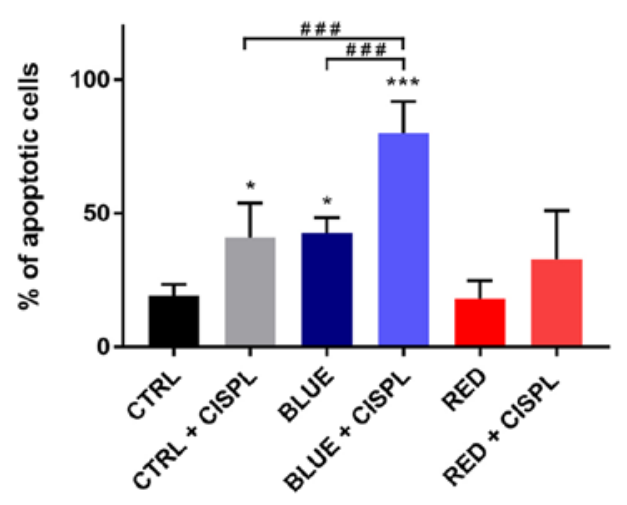

C

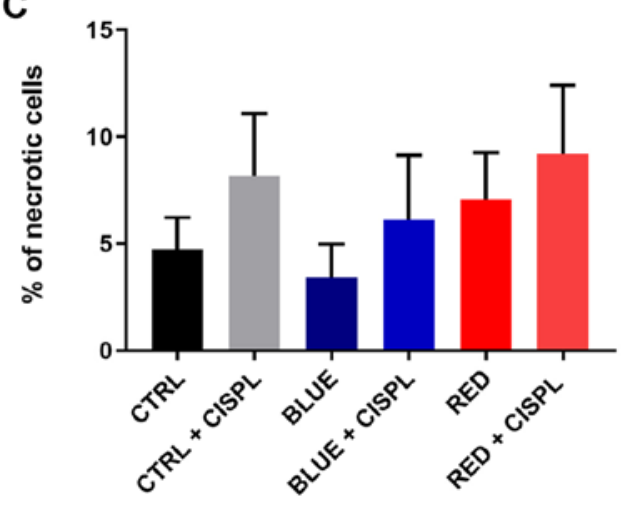

E

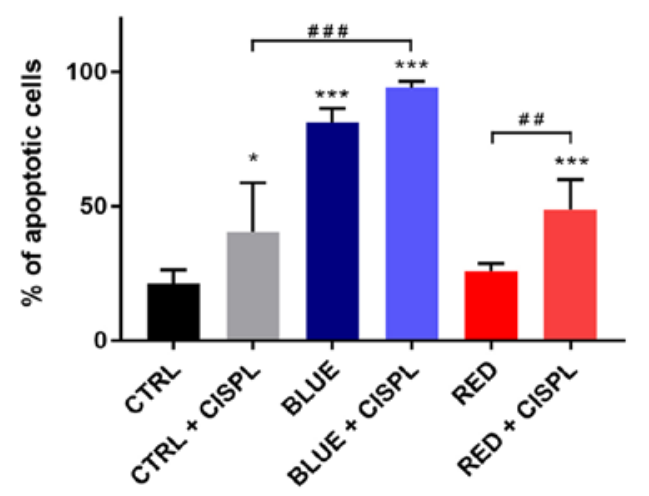

$\mathbf{F}$

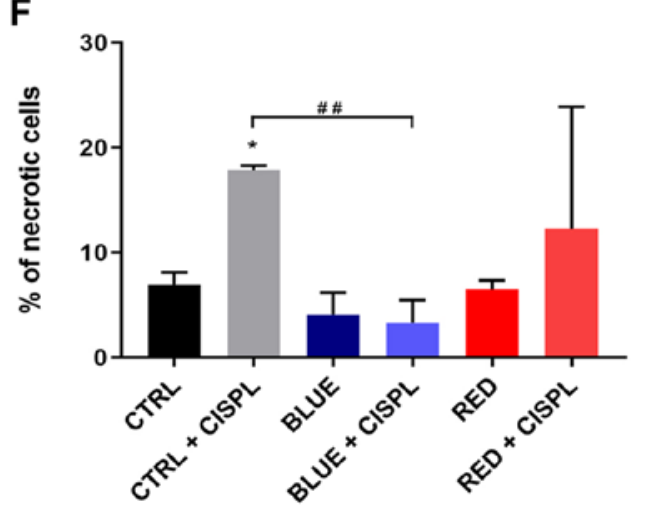

Figure 3. Apoptotic and necrotic effects of exposure of A431 and HaCaT cells to LED, cisplatinum, and LED and cisplatinum combined. Data indicate the percentage of apoptotic (Annexin $\mathrm{V}+$ ) and necrotic (Annexin $\mathrm{V}^{-} / \mathrm{PI}^{+}$) cells of the (A-C) A431 and (D-F) HaCaT cell lines. Columns represent mean values and bars represent $\pm \mathrm{SD}(\mathrm{n}=3)$. ${ }^{*} \mathrm{P}<0.05$, and ${ }^{* * * *} \mathrm{P}<0.001$ vs. CTRL. ${ }^{\# \#} \mathrm{P}<0.01$ and ${ }^{\# \# \#} \mathrm{P}<0.001$. LED, light-emitting diode; SD, standard deviation. 
A

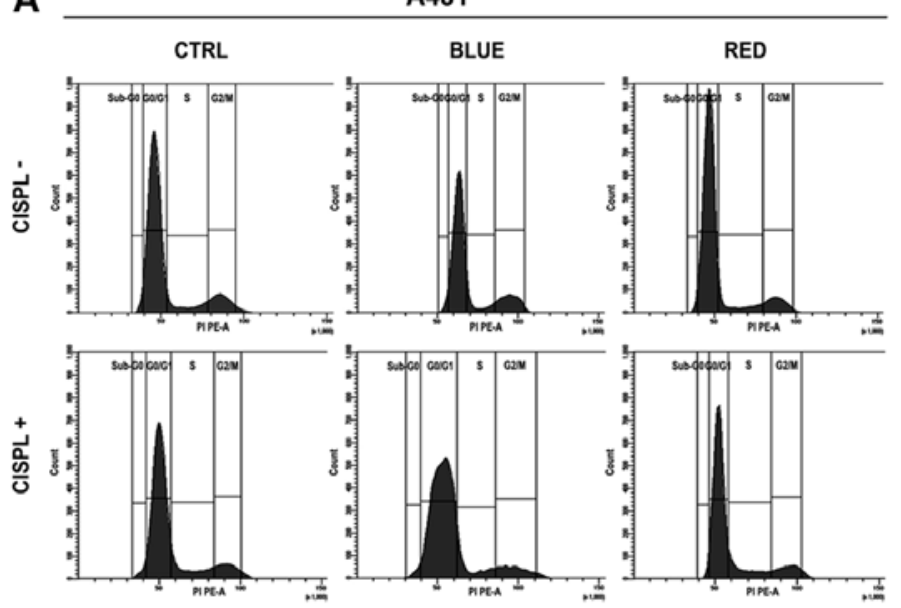

B

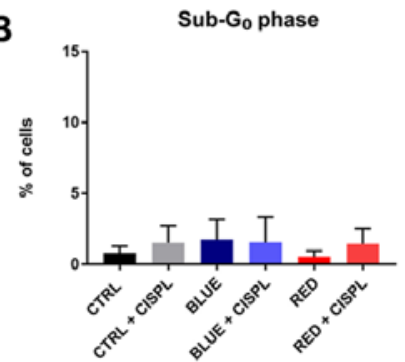

D

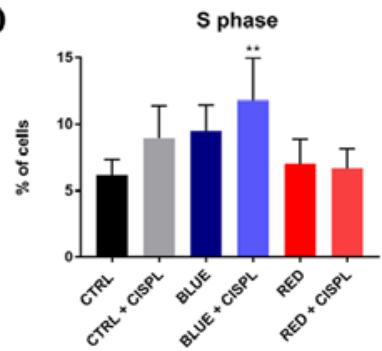

C

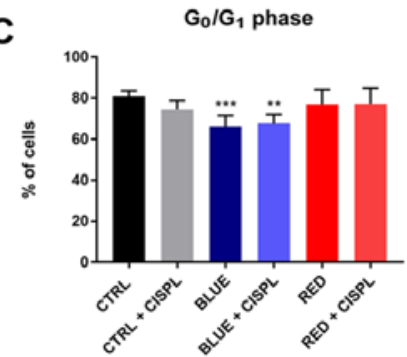

E

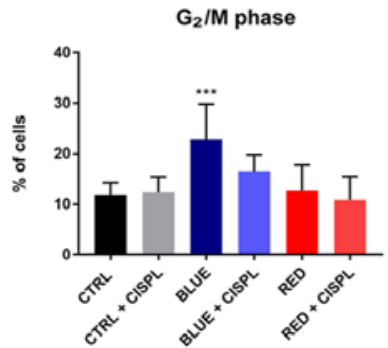

$\mathbf{F}$

HaCaT
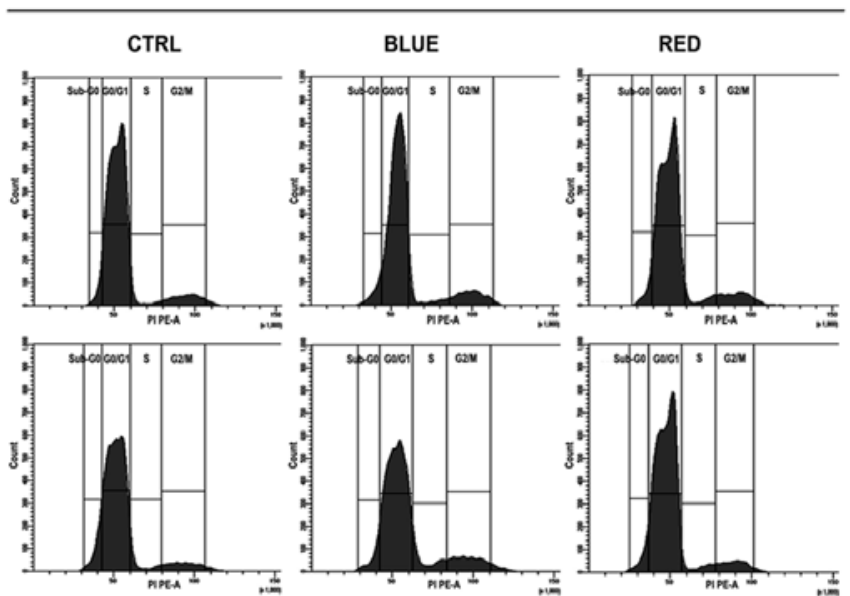

G

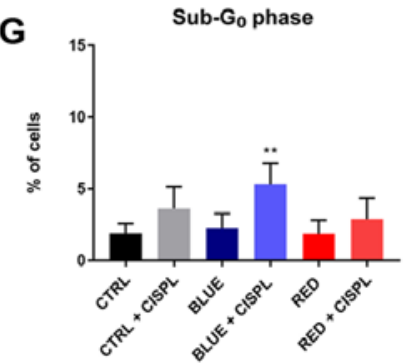

H

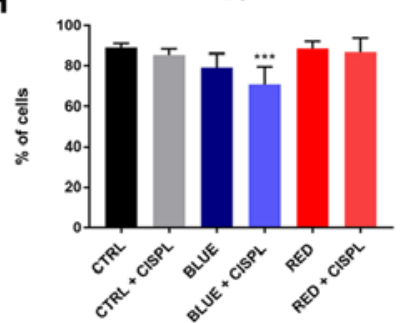

I

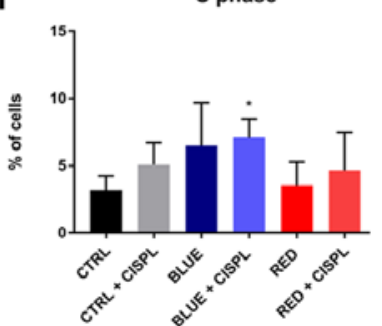

J

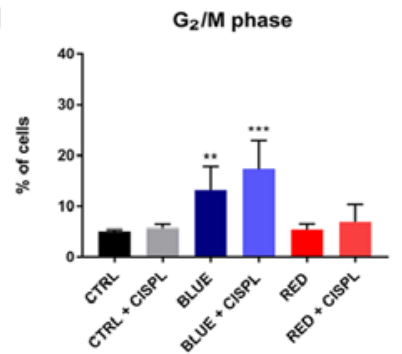

Figure 4. Effect of exposure to LED, cisplatinum, and LED and cisplatinum combined on cell cycle progression in A431 and HaCaT cells. Data indicate the effect of every treatment on the different cell cycle phases of the (A-E) A431 and (F-J) HaCaT cell lines. Columns represent mean values and bars represent $\pm \mathrm{SD}(\mathrm{n}=3) .{ }^{*} \mathrm{P}<0.01,{ }^{* *} \mathrm{P}<0.001$ and ${ }^{* * *} \mathrm{P}<0.05$ vs. CTRL. SD, standard deviation.

\section{Results}

Combined treatment with blue light and cisplatinum is more effective in reducing cell viability than single treatments. The A431 and HaCaT cells were treated to assess whether the combination of cisplatinum and different light spectra decreased cell viability, as compared to the single treatments. The viability of the tumor cells was markedly inhibited following exposure to blue light (BLUE), as compared to the untreated cells (CTRL) $(\mathrm{P}<0.001$; Figs. 1 and $2 \mathrm{~A})$. The higher percentage of inhibition in viable cells was obtained with blue light and cisplatinum (BLUE + CISPL), as compared to the CTRL group and CTRL + CISPL group $(\mathrm{P}<0.001)$. On the contrary, neither irradiation with red light alone (RED) nor treatment with red light and cisplatinum (RED + CISPL) led to a marked reduction in tumor cell viability, when compared with the untreated cells. Treatment with red light and cisplatinum increased A431 cell viability, as compared to the CTRL + CISPL group $(\mathrm{P}<0.001)$. The results obtained for the RED + CISPL group were similar to those of the CTRL, but lower than those of the RED group $(\mathrm{P}<0.05)$.
The HaCaT cells (Figs. 1 and 2B) displayed a notable decrease in viability in the BLUE and BLUE + CISPL groups compared to the CTRL group $(\mathrm{P}<0.001)$. In addition, cell viability was reduced in the BLUE + CISPL group, as compared to CTRL + CISPL group $(\mathrm{P}<0.001)$. With regards to the RED group, the results were different than those obtained from the A431 cells, since the RED + CISPL exhibited a lower cell viability $(\mathrm{P}<0.001$ vs. $\mathrm{CTRL} ; \mathrm{P}<0.001$ vs. $\mathrm{RED})$.

Combined treatment with blue light and cisplatinum yields a higher percentage of apoptotic cells than single treatments. Flow cytometry confirmed that CTRL + CISPL, BLUE and BLUE + CISPL caused a significant increase in the apoptotic rate (Annexin V-positive cells), as compared to the CTRL in both cell lines (Fig. 3A, B and E). These results revealed that the BLUE + CISPL group exhibited an increase in the number of apoptotic A431 cells (mean, 80.1\%), as compared to the CTRL + CISPL (mean, 40.5\%; P<0.001) or BLUE (mean, 42.6\%; $\mathrm{P}<0.001$ ) groups. The HaCaT cell line displayed an increased apoptotic rate in the BLUE + CISPL group, as compared to the CTRL group $(\mathrm{P}<0.001)$ (Fig. 3D and E). On 
A

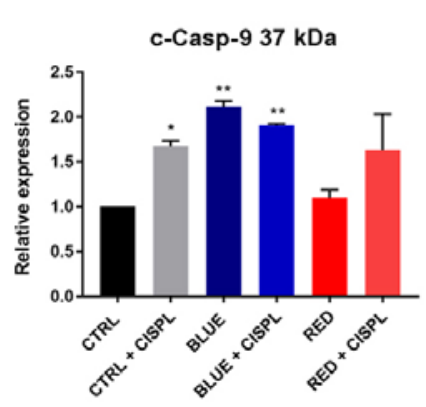

c-Casp-8 $43 \mathrm{kDa}$

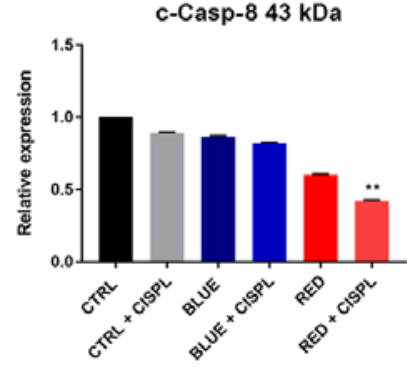

A431
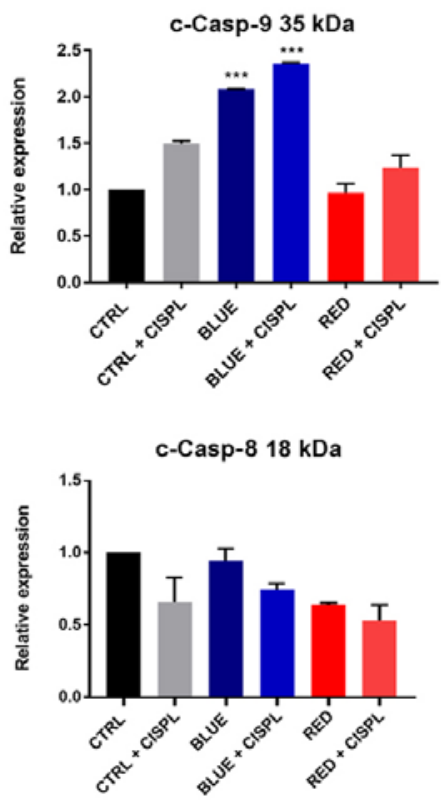

C-Casp-3 $17 \mathrm{kDa}$

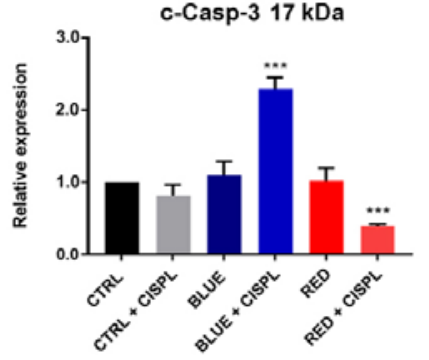

B
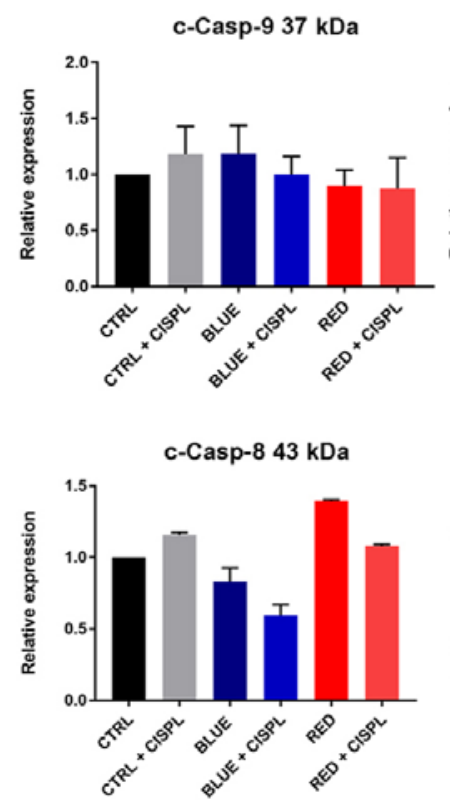

HaCaT

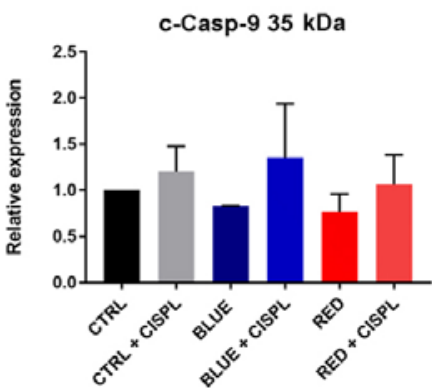

c-Casp-8 $18 \mathrm{kDa}$

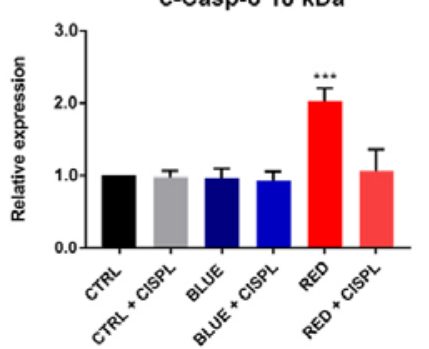

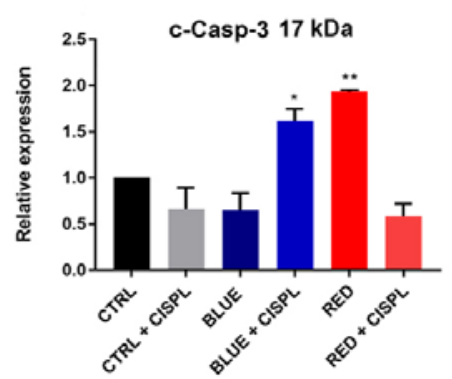

Figure 5. Analysis of apoptosis-related proteins Casp-9, Casp-8 and Casp-3 expression levels in cell lysates from (A) A431 and (B) HaCaT cells. Values were normalized to GAPDH. Columns represent mean values and bars represent $\pm \mathrm{SD}(\mathrm{n}=3)$. ${ }^{*} \mathrm{P}<0.05,{ }^{* *} \mathrm{P}<0.01$ and ${ }^{* * * *} \mathrm{P}<0.001$ vs. CTRL. Representative blot bands are presented in Fig. S1. SD, standard deviation; Casp, caspase.

the other hand, a high quantity of HaCaT cells undergoing apoptosis was also observed, even when treated with blue light alone ( $\mathrm{P}<0.001$ vs. CTRL) (Fig. 3D and E). The RED and RED + CISPL groups exhibited a percentage of apoptotic and necrotic A431 cells similar to the CTRL (Fig. 3A, B and C). With regards to the HaCaT cells, the RED + CISPL group exhibited a significant increase in the percentage of apoptotic cells with respect to the CTRL and RED groups $(\mathrm{P}<0.001$ and $\mathrm{P}<0.01$ respectively; Fig. $3 \mathrm{D}$ and $\mathrm{E}$ ).

Combined treatment with blue light and cisplatinum leads to $S$ and $G 2 / M$ cell cycle arrest. Cell cycle analysis indicated that the A431 cells treated with BLUE + CISPL were arrested at the $\mathrm{S}$ phase $(\mathrm{P}<0.01$; Fig. $4 \mathrm{~A}$ and $\mathrm{D})$, while the percentage of cells in the G0/G1 checkpoint was significantly lower, as compared to the CTRL ( $\mathrm{P}<0.01$; Fig. $4 \mathrm{~A}$ and $\mathrm{C}$ ). The BLUE group exhibited lower percentages of cells in the $G_{0} / G_{1}$ and higher ones in the $\mathrm{G}_{2} / \mathrm{M}$ phase, as compared to the CTRL $(\mathrm{P}<0.001$; Fig. 4A, C and E). With regards to the HaCaT cell line, cell cycle analysis indicated that the number of cells in the BLUE + CISPL group was significantly higher in the $\mathrm{S}$ phase and in the $G_{2} / M$ phase $(P<0.05$ and $P<0.001 ;$ Fig. $4 F$, $I$ and $J)$ and lower in the $G_{0} / G_{1}$ phase $(P<0.001$; Fig. $4 A$ and $H)$ compared with the CTRL. Furthermore, by observing the
sub-G0 phase (Fig. 4A and G), the cells in the BLUE + CISPL exhibited a higher percentage of cells in this phase, as compared to the CTRL group $(\mathrm{P}<0.01)$.

Crucial role of apoptotic key factors in the fate of A431 and HaCaT cells following treatment with light and cisplatinum. The results described above led to the investigation of the molecular mechanisms underlying the effects of the treatments used. Hence, the expression levels of cell death-related proteins, such as Casp-9, Casp-8, Casp-3, Bid, Bax, Cyt c, p53 and Aif were analyzed by western blot analysis (representative protein bands are shown in Fig. S1).

The protein expression of cleaved Casp-9 in the A431 cells was in line with the results obtained from the apoptosis and cell cycle analysis, since the two cleaved forms of the protein (cleaved at 37 and $35 \mathrm{kDa}$ ) increased upon treatment with BLUE and BLUE + CISPL, as compared to the CTRL (Fig. 5A). With regards to the $\mathrm{HaCaT}$ cell line, on the other hand, no significant changes in either $37 \mathrm{KD}$ or in $35 \mathrm{kDa}$ cleaved Casp-9 were identified (Fig. 5B). Casp-8 expression was also analyzed. Pro-caspase 8 expression was not altered among the treatments (data not shown), while the results on the Casp- 8 cleaved fragments exhibited a decreasing trend in 43 and $18 \mathrm{kDa}$ protein expression in the A431 tumor cells in all treatments, as compared 
A

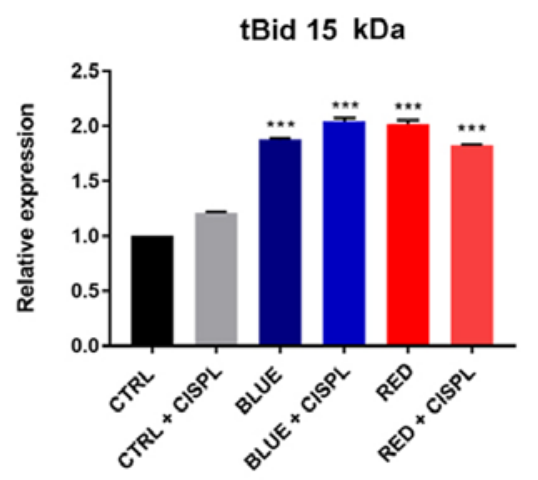

B

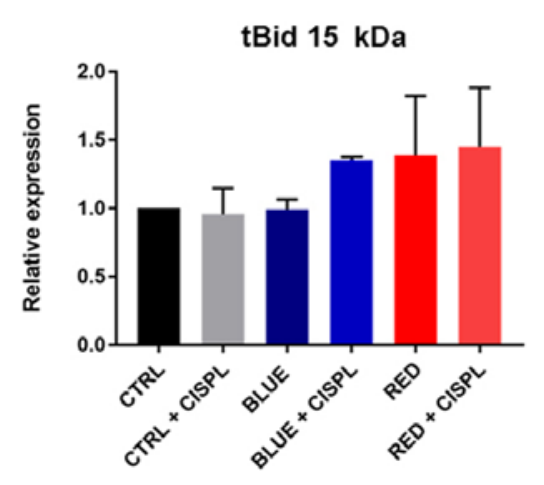

A431

Bax 23 kDa

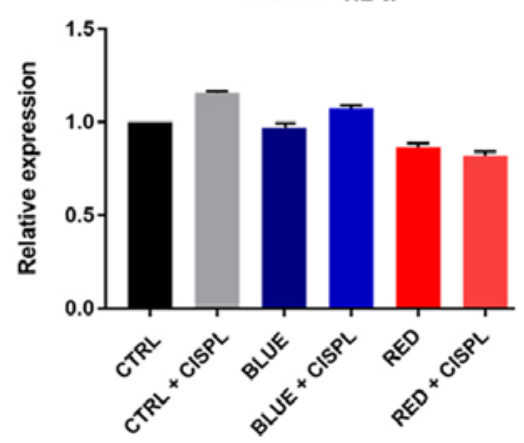

HaCaT

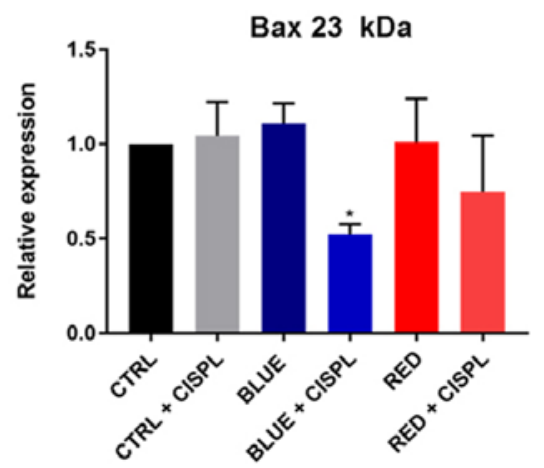

Cyt c $15 \mathrm{kDa}$
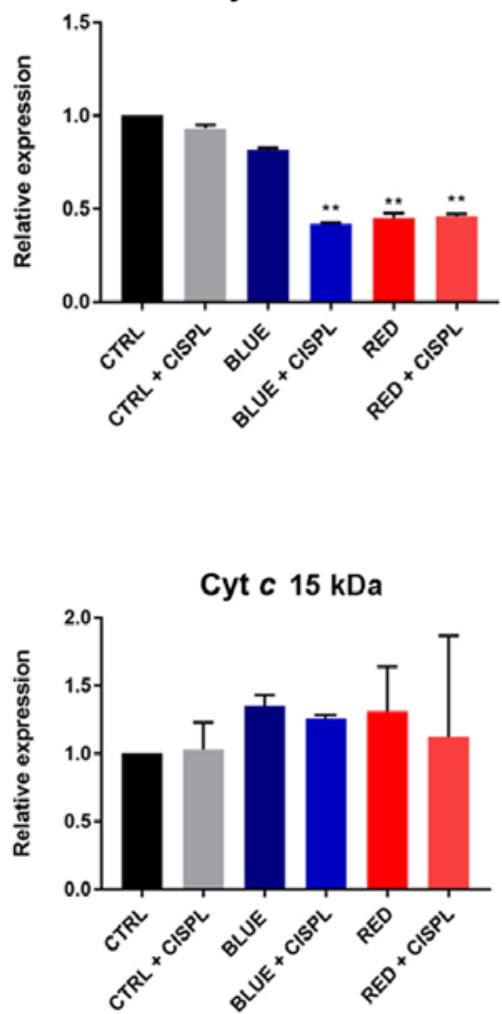

Figure 6. Western blot analysis of apoptosis-related proteins Cyt $c$, Bax and tBid in (A) A431 and (B) HaCaT cells. Values were normalized to GAPDH. Columns represent mean values and bars represent $\pm \mathrm{SD}(\mathrm{n}=3)$. ${ }^{*} \mathrm{P}<0.05,{ }^{* *} \mathrm{P}<0.01$ and ${ }^{* * * *} \mathrm{P}<0.001$ vs. CTRL. Representative blot bands are presented in Fig. S1. tBid, truncated BH3 interacting domain death agonist; Bax, Bcl-2-associated X protein; Cyt $c$, cytochrome $c$; SD, standard deviation.

to the CTRL group (Fig. 5A). However, it is important to note the higher reduction of Casp- $843 \mathrm{kDa}$ upon RED + CISPL treatment $(\mathrm{P}<0.01$ vs. CTRL). In the HaCaT cells, the cleaved Casp-8 fragment (18 kDa) was significantly increased only in the RED group ( $\mathrm{P}<0.05$ vs. CTRL; Fig. $5 \mathrm{~B})$.

The key apoptotic factor, Casp-3, in the A431 cell line at the $17 \mathrm{kDa}$ subunit level exhibited a significant increase in its expression in the BLUE + CISPL group as compared to the CTRL group $(\mathrm{P}<0.001$; Fig. 5A). The same cell line instead exhibited a decrease in the expression of Casp-3 $17 \mathrm{kDa}$ in the RED + CISPL group $(\mathrm{P}<0.001)$. In the HaCaT cells, the level of Casp-3 $17 \mathrm{kDa}$ in the BLUE + CISPL and RED groups was increased $(\mathrm{P}<0.05$ and $\mathrm{P}<0.01$, respectively; Fig. 5B).

Bid protein was assessed by analyzing the expression of its active cleaved form with a molecular weight of $15 \mathrm{kDa}$ (tBid). A significant increase was observed in its expression in the A431 cells in all groups treated with light alone and light combined with cisplatinum, as compared to the CTRL group ( $\mathrm{P}<0.001$; Fig. 6A). No significant differences in tBID expression were observed among the groups in the $\mathrm{HaCaT}$ cells (Fig. 6B).

Bax protein expression in the A431 cells was not significantly altered among the groups (Fig. 6A), while in the $\mathrm{HaCaT}$ cells, its expression was markedly decreased in the BLUE + CISPL group ( $\mathrm{P}<0.05$ vs. CTRL; Fig. 6B).

Furthermore, lower values of cytosolic Cyt $c$ were observed in the A431 cells treated with blue light combined with cisplatinum, as compared to the CTRL group $(\mathrm{P}<0.01$; Fig. 6A).

These results demonstrated that combined treatment with blue light and cisplatinum (BLUE + CISPL) effectively induced apoptosis, which was associated with a decrease in the $\mathrm{p} 53$ protein expression level in the $\mathrm{A} 431$ ( $\mathrm{P}<0.05$ vs. CTRL; Fig. 7A) and HaCaT cell lines ( $<<0.01$ vs. CTRL; Fig. 7B). In the $\mathrm{HaCaT}$ cells, all treatments led to a significant decrease in p53 expression (Fig. 7B).

With regards to the analysis of expression of the necroptosis-related protein, Aif, the data revealed a marked increase in its cleaved form $(57 \mathrm{kDa})$ in the A431 cells following exposure to blue light $(\mathrm{P}<0.05$ BLUE vs. CTRL; Fig. 7A) and blue light combined with cisplatinum $(\mathrm{P}<0.05$ BLUE + CISPL vs. CTRL). Conversely, the HaCaT cells exhibited a significant decrease in the $57 \mathrm{kDa}$-cleaved protein expression following exposure to light alone $(\mathrm{P}<0.05 \mathrm{BLUE}$ vs. $\mathrm{CTRL}$ and RED vs. CTRL; Fig. 7B) and to light followed by the addition of cisplatinum $(\mathrm{P}<0.05$ BLUE + CISPL vs. CTRL; $\mathrm{P}<0.01$ RED + CISPL vs. CTRL).

\section{Discussion}

CSCC is a type of malignant skin neoplasia with a high morbidity risk (10); hence, it is fundamental for the development of novel alternative therapies to increase tumor vulnerability. Alternative therapies using LEDs (phototherapy) 
A

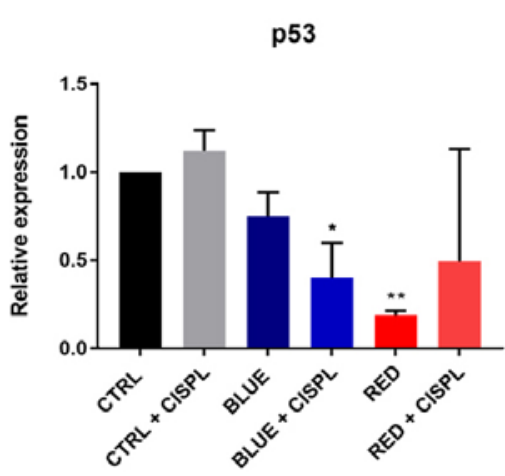

B

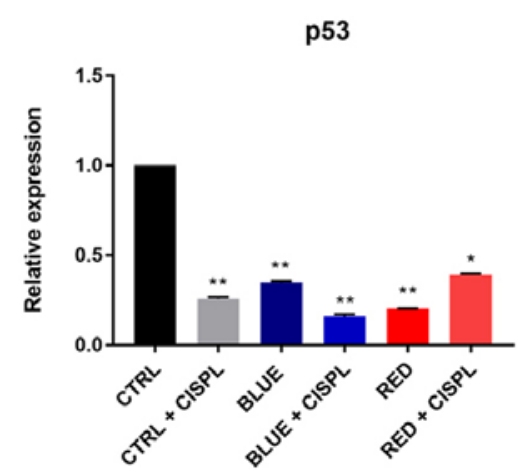

A431

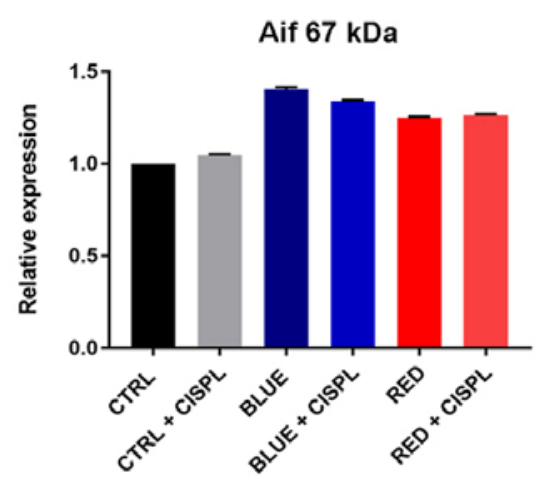

HaCaT

Aif $67 \mathrm{kDa}$

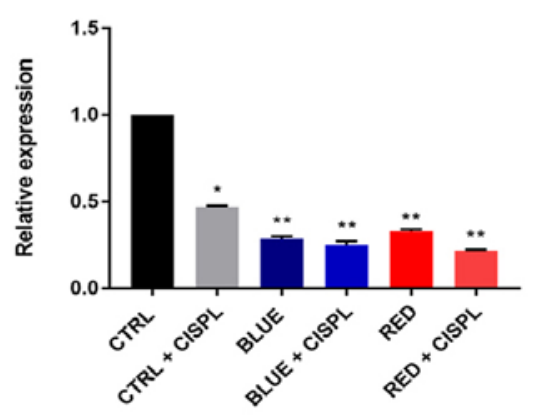

C-Aif $57 \mathrm{kDa}$

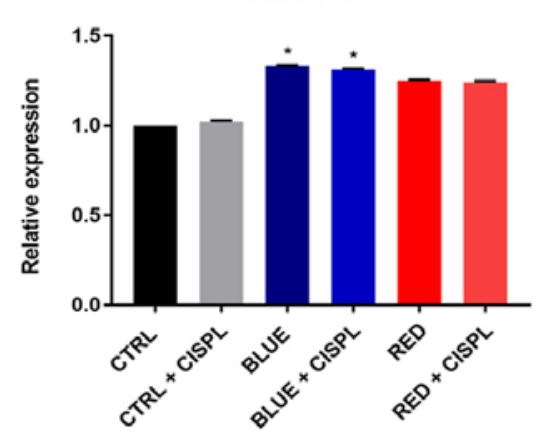

c-Aif $57 \mathrm{kDa}$

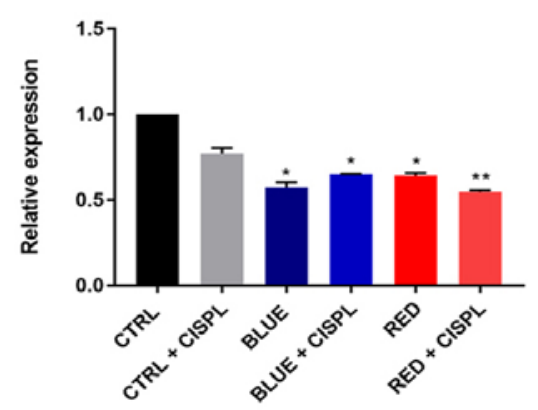

Figure 7. Western blot analysis of apoptosis-related proteins Aif and p53 in (A) A431 and (B) HaCaT cells. Values were normalized to GAPDH. Columns represent mean values and bars $\pm \mathrm{SD}(\mathrm{n}=3)$. ${ }^{*} \mathrm{P}<0.05$ and ${ }^{* *} \mathrm{P}<0.01$ vs. CTRL. Representative blot bands are presented in Fig. S1. Aif, anti-apoptosis independent; $\mathrm{SD}$, standard deviation.

in combination with chemotherapeutic agents, including cisplatinum, have recently been proposed as a different approach to tumor treatment $(12,16,32)$. In the present study, the effects of LED spectra and cisplatinum, used alone or in combination, were assessed on normal keratinocytes (HaCaT) and cSCC cancer cells (A431).

The results revealed that combined treatment was more effective on the A431 cells than single treatments, significantly decreasing cell viability and increasing the apoptotic rate. A higher effectiveness of BLUE + CISPL combined treatment was observed when A431 cells were exposed to both agents, which induced a significant increase in the percentage of apoptotic A431 cells ( 2-fold the effect of blue light as used alone). The apoptotic effects of blue light were observed in other in vitro and in vivo studies, where blue irradiation caused a decrease in cellular growth and induced cell death in skin cancer cell lines and animal models (51). A higher efficacy of blue light combined with cisplatinum on inducing apoptosis was observed in some cancer cell lines and xenograft mouse models $(32,36,51)$. The present data suggested that blue light can enhance the cytotoxic effects of cisplatinum on A431 cells, exerting a more prominent effect on apoptosis when used in combination. It was also observed that cells were more sensitive to blue light exposure alone, as compared to red light exposure alone, suggesting that the blue light is more cytotoxic than the red one. Indeed, the A431 cells displayed a high viability rate when exposed to the red light and showed no changes in the number of apoptotic cells, even under combined treatment with cisplatinum. It was thus hypothesized that somehow, red light confers to A431 cells a type of resistance to cisplatinum, which was not observed when the cells were treated with blue light and cisplatinum. This could be related to the tumorigenic features of A431 cells as HaCaT cells were otherwise sensitive to red light combined with cisplatinum.

Given current insights into the association between apoptosis and cell cycle progression, the present study then sought to determine whether there were any differences in cell cycle progression upon single or combined light and cisplatinum treatment. Focusing on BLUE + CISPL treatment, a significant increase in the percentage of cells in the $S$ and/or $G_{2} / M$ phases was observed in both normal keratinocytes and skin cancer cells, suggesting that this treatment also exerted a cytostatic effect. This was in agreement with studies describing that $\mathrm{HaCaT}$ cells have a defective $\mathrm{G}_{1}$ checkpoint, responding to UVB radiation by arresting cells in the $S$ and $G_{2}$ phases (64). The same effect was reported when HaCaT cells were exposed to blue and red LEDs together with curcumin (64).

Apoptosis is the main programmed-cell death pathway that cells form under any cytotoxic stimulus (52). There are two controlled pathways involved in apoptosis: The death receptorregulated or extrinsic pathway that activates Casp-8, and the mitochondria-controlled or intrinsic pathway that activates Casp-9 (16,65). There are other apoptosis-related proteins associated with the different pathways (intrinsic, extrinsic, or 
both), including Bax (pro-apoptotic), tBid (anti-apoptotic) and Cyt $c$, which are associated with the intrinsic pathway $(52,66)$, and p53 and Casp-3 proteins. Apart from apoptosis, other cell death mechanisms have been described, including necroptosis, in which the Aif protein plays a central role (67). To further elucidate the molecular mechanisms underlying the apoptotic process that A431 and $\mathrm{HaCaT}$ cells undergo following different treatments, the expression of diverse cell death-related proteins was analyzed.

The data obtained revealed several outcomes. The cytofluorimetric analysis indicated that cells underwent an apoptotic process since Annexin V was bound to phosphatidylserine molecules expressed in the outer membrane of apoptotic cells. It was therefore then evaluated whether the intrinsic or extrinsic apoptotic pathway was activated.

The activation of Casp-9, rather than Casp-8, in the A431 cells confirmed that cells treated with blue light and blue light combined with cisplatinum were involved in the intrinsic apoptotic pathway. The blue light activated the initiator Casp-9 but not the effector Casp-3; these results were associated with the low apoptotic rate of this treatment The advantage of using combined treatment (BLUE + CISPL) was associated with an increased expression of active effector Casp-3 subunit. However, following the further evaluation of Cyt $c$ activated by cleaved Casp-9 $(52,65,66)$, low expression values were observed. In addition, the tBid protein (associated with the extrinsic pathway) exhibited high levels in all treatments with light alone and light combined with cisplatinum. These contradictory outcomes were also observed in a study on cervical carcinoma cells, which demonstrated that Casp- 8 formed a complex with Bid, leading to its cleavage into t-Bid and to the subsequent activation of type II extrinsic apoptosis (65). However, that study also reported the formation of the Casp-8/Bid complex in cells that were undergoing mitochondrial-independent apoptosis (65). In a previous study, p53 expression, a key apoptosis-related protein, was analyzed (68). A decrease in the expression of the total protein was found in A431 cells that had undergone BLUE + CISPL combined treatment and red light exposure alone. Previous studies on the behavior of p53 against different stresses have revealed a high temporal dynamism in its expression levels. In particular, it has been observed that cells exposed to UV $(69,70)$ and cisplatinum (71) exhibited important variations of p53 protein expression. It was hypothesized that the low p53 expression identified in the cells in the present study was linked to the blue light and cisplatinum treatment, which differently modulated the p53 expression profile over time. Based on these conflicting data, it was hypothesized that cells were undergoing another type of cell death. Therefore, the expression levels of the necroptosis-related protein, Aif, were analyzed. Increased expression levels of cleaved (c-Aif) proteins were observed in the A431 cells treated with blue light alone and blue light combined with cisplatinum. These data suggest that tumor cells were undergoing necroptosis triggered by the light, given that single treatment with cisplatinum did not yield any significant increase in c-Aif expression values. In light of these results, it cannot be affirmed that A431 cells have one particular cell death mechanism, since protein expression analysis showed that, indeed, tumor cells also follow the intrinsic and extrinsic apoptotic pathways, and the necroptotic cell death mechanism. This could be explained by a possible phosphatidylserine re-localization, which has been described in other skin cancer cells under pro-apoptotic stimuli and has been speculated to induce smaller cross-reactive proteins that might lead to different cell death mechanisms working simultaneously (72).

In the HaCaT cell line, expression analysis of the same proteins did not yield well-defined results, with regards to the cell death mechanism. In fact, caspase analysis suggested the activation of the extrinsic apoptotic pathway, since cleaved-Casp-9 (37 and $35 \mathrm{kDa}$ ) expression levels were not significant at all. However, the expression of the active $18 \mathrm{kDa}$ subunit of Casp- 8 and the active $17 \mathrm{kDa}$ subunit of Casp-3 were increased following red light treatment. It is therefore likely that the $\mathrm{HaCaT}$ cells underwent extrinsic apoptosis cell death only following red light treatment. Treatment with blue light combined with cisplatinum caused only the increase of the active fragment of Casp-3; further investigations of the mechanism of cell death in $\mathrm{HaCaT}$ treated are necessary. Furthermore, p53 expression levels were low in all groups, potentially due to the expression dynamism displayed by $\mathrm{p} 53$, depending on the type and intensity of the stress (69-72). The results of the expression analysis of necroptosis-related protein Aif ruled out this cell death mechanism, since both full-length proteins and cleaved fragments were very lowly expressed in all groups.

The mechanisms leading to cell death differed in each of the analyzed cell lines. However, it can be affirmed that combined treatment, particularly BLUE + CISPL, promoted the activation of programmed cell death in both cell lines, although the exact mechanisms were not clarified. The fact that both apoptotic pathways were active in both cell lines has been supported by a recent study by Laubach et al (73) on HaCaT and A431 cells undergoing treatment with curcumin and light irradiation. That study theorized a switch in the apoptotic mechanism related to changes in cellular redox balance and a mechanism of apoptotic stimulation independent from classical death receptors. Keratinocytes and skin tumor cells were also reported to undergo different apoptotic processes, due to the different expression of apoptotic regulators and apoptotic responses involved in reaching the diverse functional needs of the skin (73).

The combination of different treatments for the targeting of cSCC has several advantages: Targeting of different key signal transduction pathways; more efficient damage caused in tumor cells; increased therapeutic efficacy; additive or even synergistic effects that allow for the dose of the most toxic component can be reduced to eliminate or lessen noxious side-effects (32). The results of the present study indicated that the combination of blue light radiation at $465 \mathrm{~nm}$ followed by cisplatinum could be used as a potential treatment for cSCC and recommended further in vivo tests and clinical trials. In particular, the use of light combined with a local cisplatinum-based treatment could be investigated in non-metastatic $\mathrm{cSCC}$, or when the conventional surgical approach is not an option. In addition, given the availability of local treatments containing 5-FU, the effect of blue radiation combined with 5-FU was investigated. Preliminary viability data (Fig. S2) revealed an effect of blue light radiation combined with 5-FU 
similar to that obtained with cisplatinum, but less significant. Since novel therapeutic strategies are being developed for cSCC (74-77), the apoptotic effect of blue-light treatment can also be investigated in combination with the new treatments for cSCC, such as immune checkpoint agents or electrochemotherapy. A limitation of the present study is the use of only one skin cancer cell line making results about A431 referred only to cSCC and not to other types of skin cancer. The use of $\mathrm{HaCaT}$ cells instead of primary human keratinocytes is another limitation, although the selection was based on the use of the same culture conditions. As regards experiments with light, it is known that the culture conditions, in particular the medium utilized, may influence the results $(78,79)$. The use of normal human epidermal keratinocytes-adult cells (NHEK cells) was attempted (data not shown). In the experiments in the present study, the NHEK cells exposed to light in the KGM-Gold medium showed a change in morphology, while in the same mediums used for A431, the NHEK cells showed extremely slow growth and a clear change in morphology (data not shown). Rather, the HaCaT cells growing in the same conditions of A431 cells made the results more comparable.

In conclusion, the data of the present study suggested that the combination of blue light and cisplatinum reduced the survival rate of A431 cells and triggered the apoptotic death of A431 cells. Further studies are required to fully elucidate the exact molecular mechanisms through which combined treatments of blue light and cisplatinum mediate apoptotic cell death, and to understand its overall mechanism in skin cancer.

\section{Acknowledgements}

Not applicable.

\section{Funding}

The present study was supported by a generous donation from iGuzzini illuminazione S.p.A. (Recanati, Italy). The funder had no role in the design of the study, the collection, analysis or interpretation of data, the writing of the manuscript, or the decision to publish the results.

\section{Availability of data and materials}

All data generated or analyzed during this study are included in this published article or are available from the corresponding author on reasonable request.

\section{Authors' contributions}

MB, MFT, MEZ and LS conceived and designed the study. MB, MFT, MEZ, RL and EMB performed the experiments. FP, CL, VR and AP were responsible for the methodology. MFT and MEZ organized and wrote the manuscript. RL, CL, VR and MB reviewed and edited the manuscript. MB and LS supervised the study. All authors read and approved the final manuscript.

\section{Ethics approval and consent to participate}

Not applicable.

\section{Patient consent for publication}

Not applicable.

\section{Competing interests}

The authors declare that they have no competing interests.

\section{References}

1. Barolet D, Roberge CJ, Auger FA, Boucher A and Germain L: Regulation of skin collagen metabolism in vitro using a pulsed $660 \mathrm{~nm}$ LED light source: Clinical correlation with a single-blinded study. J Invest Dermatol 129: 2751-2759, 2009.

2. Mateus C: Cutaneous squamous cell carcinoma. Rev Prat 64: 45-52, 2014.

3. Parekh V and Seykora JT: Cutaneous squamous cell carcinoma. Clin Lab Med 37: 503-525, 2017.

4. Smoller BR: Squamous cell carcinoma: From precursor lesions to high-risk variants. Mod Pathol 19 (Suppl 2): S88-S92, 2006.

5. Palme CE, MacKay SG, Kalnins I, Morgan GJ and Veness MJ: The need for a better prognostic staging system in patients with metastatic cutaneous squamous cell carcinoma of the head and neck. Curr Opin Otolaryngol Head Neck Surg 15: 103-106, 2007.

6. Garcia-Zuazaga J and Olbricht SM: Cutaneous squamous cell carcinoma. Adv Dermatol 24: 33-57, 2008.

7. Kyrgidis A, Tzellos TG, Kechagias N, Patrikidou A, Xirou P, Kitikidou K, Bourlidou E, Vahtsevanos K and Antoniades K: Cutaneous squamous cell carcinoma (SCC) of the head and neck: Risk factors of overall and recurrence-free survival. Eur J Cancer 46: 1563-1572, 2010.

8. Clayman GL, Lee JJ, Holsinger FC, Zhou X, Duvic M, El-Naggar AK, Prieto VG, Altamirano E, Tucker SL, Strom SS, et al: Mortality risk from squamous cell skin cancer. J Clin Oncol 23: 759-765, 2005.

9. Sreedhar A, Li J and Zhao Y: Next-gen therapeutics for skin cancer: Nutraceuticals. Nutr Cancer 70: 697-709, 2018.

10. Burton KA, Ashack KA and Khachemoune A: Cutaneous squamous cell carcinoma: A review of high-risk and metastatic disease. Am J Clin Dermatol 17: 491-508, 2016.

11. Que SKT, Zwald FO and Schmults CD: Cutaneous squamous cell carcinoma: Management of advanced and high-stage tumors. J Am Acad Dermatol 78: 249-261, 2018.

12. Compagnin C, Mognato M, Celotti L, Canti G, Palumbo G and Reddi E: Cell proliferation and cell cycle alterations in oesophageal p53-mutated cancer cells treated with cisplatin in combination with photodynamic therapy. Cell Prolif 43: 262-274, 2010.

13. Bray FN, Simmons BJ, Wolfson AH and Nouri K: Acute and chronic cutaneous reactions to ionizing radiation therapy. Dermatol Ther (Heidelb) 6: 185-206, 2016.

14. Ando N, Kato H, Igaki H, Shinoda M, Ozawa S, Shimizu H, Nakamura T, Yabusaki H, Aoyama N, Kurita A, et al: A randomized trial comparing postoperative adjuvant chemotherapy with cisplatin and 5-fluorouracil versus preoperative chemotherapy for localized advanced squamous cell carcinoma of the thoracic esophagus (JCOG9907). Ann Surg Oncol 19: 68-74, 2012.

15. Salman M and Naseem I: Riboflavin as adjuvant with cisplatin: Study in mouse skin cancer model. Front Biosci (Elite Ed) 7: 242-254, 2015.

16. Dasari S and Tchounwou PB: Cisplatin in cancer therapy: Molecular mechanisms of action. Eur J Pharmacol 740: 364-378, 2014.

17. Mego M, Svetlovska D, Miskovska V, Obertova J, Palacka P, Rajec J, Sycova-Mila Z, Chovanec M, Rejlekova K, Zuzák P, et al: Phase II study of everolimus in refractory testicular germ cell tumors. Urol Oncol 34: 122.e17-122.e22, 2016.

18. Terenziani M, De Pasquale MD, Bisogno G, Biasoni D, Boldrini R, Collini P, Conte M, Dall'Igna P, Inserra A, Melchionda F, et al: Malignant testicular germ cell tumors in children and adolescents: The AIEOP (Associazione Italiana Ematologia Oncologia Pediatrica) protocol. Urol Oncol 36: 502.e7-502.e13, 2018.

19. Shi T, Jiang R, Yu J, Yang H, Tu D, Dai Z, Shen Y, Zhang Y, Cheng $\mathrm{X}$, Jia $\mathrm{H}$, et al: Addition of intraperitoneal cisplatin and etoposide to first-line chemotherapy for advanced ovarian cancer: A randomised, phase 2 trial. Br J Cancer 119: 12-18, 2018. 
20. Tempfer CB, Giger-Pabst U, Seebacher V, Petersen M, Dogan A and Rezniczek GA: A phase I, single-arm, open-label, dose escalation study of intraperitoneal cisplatin and doxorubicin in patients with recurrent ovarian cancer and peritoneal carcinomatosis. Gynecol Oncol 150: 23-30, 2018.

21. Gupta S, Maheshwari A, Parab P, Mahantshetty U, Hawaldar R, Sastri Chopra S, Kerkar R, Engineer R, Tongaonkar H, Ghosh J, et al: Neoadjuvant chemotherapy followed by radical surgery versus concomitant chemotherapy and radiotherapy in patients with stage IB2, IIA, or IIB squamous cervical cancer: A randomized controlled trial. J Clin Oncol 36: 1548-1555, 2018.

22. Kitagawa R, Katsumata N, Shibata T, Kamura T, Kasamatsu T, Nakanishi T, Nishimura S, Ushijima K, Takano M, Satoh T and Yoshikawa H: Paclitaxel Plus carboplatin versus paclitaxel plus cisplatin in metastatic or recurrent cervical cancer: The open-label randomized phase III trial JCOG0505. J Clin Oncol 33: 2129-2135, 2015.

23. Rosen VM, Guerra I, McCormack M, Nogueira-Rodrigues A, Sasse A, Munk VC and Shang A: Systematic review and network meta-analysis of bevacizumab plus first-line topotecan-paclitaxel or cisplatin-paclitaxel versus non-bevacizumab-containing therapies in persistent, recurrent, or metastatic cervical cancer. Int J Gynecol Cancer 27: 1237-1246, 2017.

24. Small W Jr, Bacon MA, Bajaj A, Chuang LT, Fisher BJ, Harkenrider MM, Jhingran A, Kitchener HC, Mileshkin LR, Viswanathan AN and Gaffney DK: Cervical cancer: A global health crisis. Cancer 123: 2404-2412, 2017.

25. Noronha V, Joshi A, Patil VM, Agarwal J, Ghosh-Laskar S, Budrukkar A, Murthy V, Gupta T, D'Cruz AK, Banavali S, et al: Once-a-week versus once-every-3-weeks cisplatin chemoradiation for locally advanced head and neck cancer: A phase III randomized noninferiority trial. J Clin Oncol 36: 1064-1072, 2018.

26. Strojan P, Vermorken JB, Beitler JJ, Saba NF, Haigentz M $\mathrm{Jr}$, Bossi P, Worden FP, Langendijk JA, Eisbruch A, Mendenhall WM, et al: Cumulative cisplatin dose in concurrent chemoradiotherapy for head and neck cancer: A systematic review. Head Neck 38 (Suppl 1): E2151-E2158, 2016.

27. Szturz P, Wouters K, Kiyota N, Tahara M, Prabhash K, Noronha V, Castro A, Licitra L, Adelstein D and Vermorken JB: Weekly low-dose versus three-weekly high-dose cisplatin for concurrent chemoradiation in locoregionally advanced non-nasopharyngeal head and neck cancer: A systematic review and meta-analysis of aggregate data. Oncologist 22: 1056-1066, 2017.

28. Gridelli C, Morabito A, Cavanna L, Luciani A, Maione P, Bonanno L, Filipazzi V, Leo S, Cinieri S, Ciardiello F, et al: Cisplatin-based first-line treatment of elderly patients with advanced non-small-cell lung cancer: Joint analysis of MILES-3 and MILES-4 phase III trials. J Clin Oncol 36: 2585-2592, 2018.

29. Rossi A and Di Maio M: Platinum-based chemotherapy in advanced non-small-cell lung cancer: Optimal number of treatment cycles. Expert Rev Anticancer Ther 16: 653-660, 2016.

30. Sarin N, Engel F, Kalayda GV, Mannewitz M, Cinatl J Jr, Rothweiler F, Michaelis M, Saafan H, Ritter CA, Jaehde U and Frötschl R: Cisplatin resistance in non-small cell lung cancer cells is associated with an abrogation of cisplatin-induced G2/M cell cycle arrest. PLoS One 12: e0181081, 2017.

31. Liu L, Fan J, Ai G, Liu J, Luo N, Li C and Cheng Z: Berberine in combination with cisplatin induces necroptosis and apoptosis in ovarian cancer cells. Biol Res 52: 37, 2019.

32. de Freitas LM, Soares CP and Fontana CR: Synergistic effect of photodynamic therapy and cisplatin: A novel approach for cervical cancer. J Photochem Photobiol B 140: 365-373, 2014.

33. Oun R, Moussa YE and Wheate NJ: The side effects of platinum-based chemotherapy drugs: A review for chemists. Dalton Trans 47: 6645-6653, 2018

34. Crul M, van Waardenburg RC, Beijnen JH and Schellens JH: DNA-based drug interactions of cisplatin. Cancer Treat Rev 28 291-303, 2002

35. Fuertes MA, Alonso C and Pérez JM: Biochemical modulation of cisplatin mechanisms of action: Enhancement of antitumor activity and circumvention of drug resistance. Chem Rev 103 645-662, 2003

36. Oh PS and Jeong HJ: Therapeutic application of light emitting diode: Photo-oncomic approach. J Photochem Photobiol B 192: 1-7, 2019.

37. Sorbellini E, Rucco M and Rinaldi F: Photodynamic and photobiological effects of light-emitting diode (LED) therapy in dermatological disease: An update. Lasers Med Sci 33: $1431-1439,2018$
38. Brancaleon L and Moseley $\mathrm{H}$ : Laser and non-laser light sources for photodynamic therapy. Lasers Med Sci 17: 173-186, 2002

39. Ost D: Photodynamic therapy in lung cancer. A review. Methods Mol Med 75: 507-526, 2003.

40. Sutedja TG and Postmus PE: Photodynamic therapy in lung cancer. A review. J Photochem Photobiol B 36: 199-204, 1996.

41. Silva JN, Filipe P, Morlière P, Mazière JC, Freitas JP, Gomes MM and Santus R: Photodynamic therapy: Dermatology and ophthalmology as main fields of current applications in clinic. Biomed Mater Eng 18: 319-327, 2008.

42. Breskey JD, Lacey SE, Vesper BJ, Paradise WA, Radosevich JA and Colvard MD: Photodynamic therapy: Occupational hazards and preventative recommendations for clinical administration by healthcare providers. Photomed Laser Surg 31: 398-407, 2013.

43. del Olmo-Aguado S, Manso AG and Osborne NN: Light might directly affect retinal ganglion cell mitochondria to potentially influence function. Photochem Photobiol 88: 1346-1355, 2012.

44. Chui C, Hiratsuka K, Aoki A, Takeuchi Y, Abiko Y and Izumi Y: Blue LED inhibits the growth of Porphyromonas gingivalis by suppressing the expression of genes associated with DNA replication and cell division. Lasers Surg Med 44: 856-864, 2012.

45. Rybchyn MS, De Silva WGM, Sequeira VB, McCarthy BY, Dilley AV, Dixon KM, Halliday GM and Mason RS: Enhanced repair of UV-induced DNA damage by 1,25-dihydroxyvitamin D3 in skin is linked to pathways that control cellular energy. J Invest Dermatol 138: 1146-1156, 2018.

46. Suh SS, Lee SG, Youn UJ, Han SJ, Kim IC and Kim S: Comprehensive expression profiling and functional network analysis of porphyra-334, one mycosporine-like amino acid (MAA), in human keratinocyte exposed with UV-radiation. Mar Drugs 15: 196, 2017.

47. Muhammad S, Qasid SH, Rehman S and Rai AB: Visible light communication applications in healthcare. Technol Health Care 24: 135-138, 2016

48. Tsibadze A, Chikvaidze E, Katsitadze A, Kvachadze I, Tskhvediani $\mathrm{N}$ and Chikviladze A: Visible light and human skin (Review). Georgian Med News: 46-53, 2015 (In Russian).

49. Gegotek A, Atalay S, Domingues P and Skrzydlewska E: The differences in the proteome profile of cannabidiol-treated skin fibroblasts following UVA or UVB irradiation in 2D and 3D cell cultures. Cells 8: 995, 2019.

50. Zhang C, Yuchi H, Sun L, Zhou X and Lin J: Human amnion-derived mesenchymal stem cells protect against UVA irradiation-induced human dermal fibroblast senescence, in vitro. Mol Med Rep 16: 2016-2022, 2017.

51. Patel AD, Rotenberg S, Messer RL, Wataha JC, Ogbureke KU, McCloud VV, Lockwood P, Hsu S and Lewis JB: Blue light activates phase 2 response proteins and slows growth of a 431 epidermoid carcinoma xenografts. Anticancer Res 34: 6305-6313, 2014.

52. Niu T, Tian Y, Wang G, Guo G, Tong Y and Shi Y: Inhibition of ROS-NF-kB-dependent autophagy enhances hypocrellin A united LED red light-induced apoptosis in squamous carcinoma A431 cells. Cell Signal 69: 109550, 2020.

53. Meulemans J, Delaere P and Vander Poorten V: Photodynamic therapy in head and neck cancer: Indications, outcomes, and future prospects. Curr Opin Otolaryngol Head Neck Surg 27: 136-141, 2019.

54. Kerr C, Adhikary G, Grun D, George N and Eckert RL: Combination cisplatin and sulforaphane treatment reduces proliferation, invasion, and tumor formation in epidermal squamous cell carcinoma. Mol Carcinog 57: 3-11, 2018.

55. Hwang H, Biswas R, Chung PS and Ahn JC: Modulation of EGFR and ROS induced cytochrome c release by combination of photodynamic therapy and carboplatin in human cultured head and neck cancer cells and tumor xenograft in nude mice. J Photochem Photobiol B 128: 70-77, 2013.

56. Zhang X, Liu X, Kang S, Liu C and Hao Y: Resveratrol enhances the effects of ALA-PDT on skin squamous cells A431 through p38/MAPK signaling pathway. Cancer Biomark 21: 797-803, 2018.

57. Tampucci S, Carpi S, Digiacomo M, Polini B, Fogli S, Burgalassi S, Macchia M, Nieri P, Manera C and Monti D: Diclofenac-derived hybrids for treatment of actinic keratosis and squamous cell carcinoma. Molecules 24: 1793, 2019.

58. Carbone C, Martins-Gomes C, Pepe V, Silva AM, Musumeci T, Puglisi G, Furneri PM and Souto EB: Repurposing itraconazole to the benefit of skin cancer treatment: A combined azole-DDAB nanoencapsulation strategy. Colloids Surf B Biointerfaces 167: 337-344, 2018 
59. Chen H, Pan J, Zhang L, Chen L, Qi H, Zhong M, Shi X, Du J and Li Q: Downregulation of estrogen-related receptor alpha inhibits human cutaneous squamous cell carcinoma cell proliferation and migration by regulating EMT via fibronectin and STAT3 signaling pathways. Eur J Pharmacol 825: 133-142, 2018.

60. Ou C, Liu H, Ding Z and Zhou L: Chloroquine promotes gefitinib-induced apoptosis by inhibiting protective autophagy in cutaneous squamous cell carcinoma. Mol Med Rep 20: 4855-4866, 2019.

61. Fusenig NE and Boukamp P: Multiple stages and genetic alterations in immortalization, malignant transformation, and tumor progression of human skin keratinocytes. Mol Carcinog 23: 144-158, 1998

62. Colombo I, Sangiovanni E, Maggio R, Mattozzi C, Zava S, Corbett Y,Fumagalli M, Carlino C, Corsetto PA, Scaccabarozzi D, et al: $\mathrm{HaCaT}$ cells as a reliable in vitro differentiation model to dissect the inflammatory/repair response of human keratinocytes. Mediators Inflamm 2017:7435621, 2017.

63. Cordero RR, Damiani A, Seckmeyer G, Jorquera J, Caballero M, Rowe P, Ferrer J, Mubarak R, Carrasco J, Rondanelli R, et al: The solar spectrum in the atacama desert. Sci Rep 6: 22457, 2016.

64. Faurschou A, Gniadecki R, Calay D and Wulf HC: TNF-alpha impairs the S-G2/M cell cycle checkpoint and cyclobutane pyrimidine dimer repair in premalignant skin cells: Role of the PI3K-Akt pathway. J Invest Dermatol 128: 2069-2077, 2008.

65. Schug ZT, Gonzalvez F, Houtkooper RH, Vaz FM and Gottlieb E: BID is cleaved by caspase- 8 within a native complex on the mitochondrial membrane. Cell Death Differ 18: 538-548, 2011.

66 . Huang $\mathrm{C}$ and $\mathrm{Yu} \mathrm{Y}$ : Synergistic cytotoxicity of $\beta$-elemene and cisplatin in gingival squamous cell carcinoma by inhibition of STAT3 signaling pathway. Med Sci Monit 23: 1507-1513, 2017.

67. Tao JX, Zhou WC and Zhu XG: Mitochondria as potential targets and initiators of the blue light hazard to the retina. Oxid Med Cell Longev 2019: 6435364, 2019.

68. Hientz K, Mohr A, Bhakta-Guha D and Efferth T: The role of p53 in cancer drug resistance and targeted chemotherapy. Oncotarget 8: 8921-8946, 2017.

69. Batchelor E and Loewer A: Recent progress and open challenges in modeling p53 dynamics in single cells. Curr Opin Syst Biol 3: $54-59,2017$.
70. Batchelor E,Loewer A, Mock C and Lahav G: Stimulus-dependent dynamics of p53 in single cells. Mol Syst Biol 7: 488, 2011.

71. Paek AL, Liu JC, Loewer A, Forrester WC and Lahav G: Cell-to-cell variation in p53 dynamics leads to fractional killing. Cell 165: 631-642, 2016.

72. Bowen AR, Hanks AN, Allen SM, Alexander A, Diedrich MJ and Grossman D: Apoptosis regulators and responses in human melanocytic and keratinocytic cells. J Invest Dermatol 120: 48-55, 2003.

73. Laubach V, Kaufmann R, Bernd A, Kippenberger S and Zöller N: Extrinsic or intrinsic apoptosis by curcumin and light: Still a mystery. Int J Mol Sci 20: 905. 2019.

74. Cives M, Mannavola F, Lospalluti L, Sergi MC, Cazzato G, Filoni E, Cavallo F, Giudice G, Stucci LS, Porta C and Tucci M: Non-melanoma skin cancers: Biological and clinical features. Int J Mol Sci 21: 5394, 2020.

75. Gargiulo M, Papa A, Capasso P, Moio M, Cubicciotti E and Parascandolo S: Electrochemotherapy for non-melanoma head and neck cancers: Clinical outcomes in 25 patients. Ann Surg 255: 1158-1164, 2012.

76. Goggins CA and Khachemoune A: The use of electrochemotherapy in combination with immunotherapy in the treatment of metastatic melanoma: A focused review. Int J Dermatol 58: 865-870, 2019

77. Montuori M, Santurro L, Feliziani A, DE Sanctis F, Ricciardi E, Gaudio D, Campione E, Bianchi L, Silvi MB and Rossi P. Electrochemotherapy for basocellular and squamocellular head and neck cancer: preliminary experience in day surgery unit. G Ital Dermatol Venereol 153: 19-25, 2018.

78. Grzelak A, Rychlik B and Bartosz G: Light-dependent generation of reactive oxygen species in cell culture media. Free Radic Biol Med 30:1418-1425, 2001.

79. Stockley JH, Evans K, Matthey M, Volbracht K, Agathou S, Mukanowa J, Burrone J and Káradóttir RT: Surpassing light-induced cell damage in vitro with novel cell culture media. Sci Rep 7: 849, 2017

This work is licensed under a Creative Commons Attribution-NonCommercial-NoDerivatives 4.0 International (CC BY-NC-ND 4.0) License. 